VI. Observations respecting a Species of Phalarope, and some other rare British Birds. By Mr:T.W. Simmonds. Communicated by Adrian Hardy Hareorth, Esq. F.L.S.

Read June 19, 1804.

The following observations are humbly offered to the Linnean Society, but with sincere regret that they are not either more numerous or important. They were made during a voyage in which I had the honour to accompany Mr. Robert Stevenson, civil engineer, of Edinburgh, on his annual inspection of the northern lighthouses.

\title{
Phalaropus Wilitamii.
}

Ph. orbitis albis, capite fusco vel cinereo.

Length 7 inches. Bill $\div$ inch, tapering, slender, acute, bending downwards at the point. Feet black, compressed. Toes united as far as the first, second, and third joints of the inner, middle, and outermost toes respectively; the remaining part of the toes webbed; the margins of the web scolloped, and somewhat of a pectinated appearance. Claws black. Eyelids white.

\section{Mas.}

Head, neck, and back dusky-brown : feathers of the front margined with light rusty and white. Fore part of the neck and breast variegated with cinereous, very pale susty and white. On each side of the neck a pale ferruginous spot. Chin, throat, belly, and under tail coverts white. 'The least wing coverts, long 
long secondaries, and upper tail coverts, margined with light rusty. Quill feathers black. Greater wing coverts, and secondary quill feathers, tipped with white, thus forming a bar on the wings. Under wing coverts pale, cinereous, or white. 'Tail feathers ten: two middle feathers longer, black; the others cincreous, tipped, and margined with white, as are also the lateral tail coverts.

\section{Fominu.}

Head dusky black. 'Throat white. On the fore part of the neck a deep ferruginous red spot, extending upwards, on each side of the neck, towards the head, and thus nearly encircling the neck, but intercepted by a very narrow streak of dark cinereous, which is continued from the head to the back. The dusky streaks on the back much fewer, and more pale; the cinereous colour every where much darker.

From this imperfect description, it may be perceived that the male of this species agrees with the Red Phalarope, var. A. of Dr. Latham, which is figured in the frontispiece of the 5th rol. of his Synopsis. The figure and general description agree exact$\mathrm{ly}$; but the words " an irregular large spot of a deep ferruginous colour" seem more applicable to the colour of the neck of the female.

The description of the Red Phalarope differs, as the size of that is greater, and "through the eye, from the base of the bill there is a dusky streak passing backwards," which is not the case with any of these specimens.

It might have been doubted that the female was more beautiful, and even somewhat larger, than the male, had not the size, $\& c$. of the sexual organs been sufficiently evident to prevent the possibility of a mistalie. 
Six females and two males were dissected. From the small size of the ovaria, the thickness and length of the ociduct of the female, and large flaccid testes of the male, it was concluded that the eggs had not been long laid, and that the males were not young ones, as their less bright plumage at first gave reason to suspect.

From the deficiency of feathers on the belly of the male, from the duller plumage, from the very few that appcared, and from the difficulty which these required to be driven from those tufts where the nests perhaps were, Would it be absurd to suppose that the males alone perform the business of incubation?

These birds were found at the edge of two or three fresh-water lakes in Sanda and North Ronaldsha, the two most northern of the Orkney islands.

In the stomachs of several were found the remains of monoculi and onisci. As none of the inhabitants had observed them before, they had no provincial name, nor was it possible to ascertain whether they frequented any of the other islands. It is much more to be regretted that the search after their nests was not attended with the desired success.

If upon more accurate inquiry this should prove to be a new species, perhaps there would be no objection to the name Williamsii, as it is to the liberality of Mr. J. Williams, of Dartford, that I am indebted for the discovery.

\section{Tringa ALPINA.}

Found on the islands of South Ronaldsha and Sanda, and at Loch Strathbeg, near Frazerburgl, Aberdeenshire.

Nest, with Charetrius hiaticula and Tringa varellus, composed of dried tufts of Juncus squarrosus deposited in a slight hole in the ground. Eggs four, smoky white, irregularly marked with 
light and darker brown blotches, rather more distinct and paler at the smaller end.

\section{LaRUS PARASITICUS.}

Found on the Isle of Glass, or Scalpa, most plentifully.

Several varieties were examined, and confirmed the remark, that there is no cxternal mark of distinction between the sexes. Nest upon the slope of a marshy hill, composed of dried grass. Eggs very light brown. marked irregularly with deep-seated dark brown blotches.

\section{Larus tridactycus.}

On the Isle of Glass, Troup Head, Fowls' heaugh, near Montrose, Isle of Bass, in the Forth.

Nest composed of dried conferva. Eggs white, with black and brown spots. The young are brought to Edinburgh market, with the gannet, and sold as articles of food.

\section{LARUS Marinus.}

Qbserved on the Isle of Glass.

\section{Larus argBntatú,}

Plentiful at Lesser Cumbray, in the Firth of Clyde; no other golls, not even the mottled variety of their own species, on the island.

\section{LARUS FUSGUS.}

Abaut a mile South of Troun Head. alsa on South Ronaldsha, Pentland Skerrio, and Copinska. On many remote rocks were mottled varieties of gullo but nona any where near the bredingplaces. 
Charadrius Calidris.

I observed this species at the Mull of Cantire. 2d June.

Anas moleissima.

Most plentiful, it is said, at Papa Westray. I found a nest at Pentland Skerrie, very near the lighthouse.

\section{Mergus Serrator.}

On the fresh-water lochs in the Isle of Glass. This specimen agrees with the description of the adult male, except that the head is variegated with dull ferruginous.

The trachea determined the species and sex.

\section{Mergus Merganser.}

It will perhaps appear presumption to attempt to remove those doubts respecting this and the Dun Diver, which have so long existed.

The following reasons seem almost convincing that the M. Merganser and Castor are merely varieties of the same species, depending upon the age and sex. The tracher of the males, the vertebræ of the neck (which vary much in aquatic birds), and the intestines, in structure, number, and dimensions, are exactly similar in both. One specimen, shot last A pril, resembled in general plumage the $\boldsymbol{M}$. Castor, except that there was little or no crest, and the head was much variegated with black. Two specimens of $M$. Merganser, and two of $M$. Castor, now at Edinburgh, have each only eighteen feathers in the tail.

This bird is not scarce in Scotland during the winter season. It is called the Skeldrake, and is confounded probably with Anas Tadorna, which is more frequently met with in summer. 


\section{Tetrao Tetrix.}

The trachea is considerably enlarged at the division of the bronchix; the enlargement is not bony, like the labyrinths of some of the Duck genus, but soft and pulpy. As Dr. Latham seems to think that there is no peculiarity of structure in the trachea of any of the British Grous*, perhaps this may be a disease, though it has not much of that appearance; if not, it is a singular lusus naturæ.

- Linn. Trans. vol. iv. p. 100. 